\title{
Article \\ The Role of Eco-Apps in Encouraging Pro-Environmental Behavior of Young People Studying in Poland
}

\author{
Agata Balińska ${ }^{1, *(D)}$, Ewa Jaska ${ }^{1}(\mathbb{D})$ and Agnieszka Werenowska ${ }^{2}(\mathbb{D}$ \\ 1 Institute of Economics and Finance, Warsaw University of Life Sciences, 02-787 Warsaw, Poland; \\ ewa_jaska@sggw.edu.pl \\ 2 Management Institute, Warsaw University of Life Sciences, 02-787 Warsaw, Poland; \\ agnieszka_werenowska@sggw.edu.pl \\ * Correspondence: agata_balinska@sggw.edu.pl
}

Citation: Balińska, A.; Jaska, E.; Werenowska, A. The Role of Eco-Apps in Encouraging Pro-Environmental Behavior of Young People Studying in Poland. Energies 2021, 14, 4946. https:// doi.org/10.3390/en14164946

Academic Editors:

Wing-Keung Wong and

Antonio Barbucci

Received: 20 July 2021

Accepted: 10 August 2021

Published: 12 August 2021

Publisher's Note: MDPI stays neutral with regard to jurisdictional claims in published maps and institutional affiliations.

Copyright: (C) 2021 by the authors. Licensee MDPI, Basel, Switzerland. This article is an open access article distributed under the terms and conditions of the Creative Commons Attribution (CC BY) license (https:// creativecommons.org/licenses/by/ $4.0 /)$.
Abstract: Nowadays, protection of the natural environment is the fundamental duty and challenge of humanity. Adverse environmental changes make it necessary to encourage behaviors that will reduce our negative impact. Due to the development of media, information reaches consumers through various channels. New media, including mobile applications, are becoming increasingly popular. Their potential impact on young consumers cannot be overestimated as young people are able to modify their attitudes, behaviors and habits more easily than older ones. The main aim of this study was to recognize the use of eco-applications as a new source of information in the field of pro-environmental behavior of young people studying in Poland. The research objectives included the identification of pro-environmental behaviors most often declared by students, verifying their recognition and use of eco-applications, and determining the features of eco-app design expected by young users. The study involved the methods of desk research, in-depth interview and computerassisted web interviewing (CAWI). The empirical material obtained from 772 students representing Generation $\mathrm{Z}$ underwent quantitative and qualitative analysis, which allowed for the verification the proposed hypotheses. The respondents most often declared pro-environmental behavior in the household context. As regards eco-apps, the respondents were most likely to recognize applications promoted via traditional media. The main feature expected of eco-app design was ease of use, which does not mean that users expected the app to be in Polish, as this criterion was relatively low rated. The Mann-Whitney test and the Kruskal-Wallis test revealed relationships between such variables as gender, place of residence or income and pro-environmental behavior, the use of selected eco-apps and the expected features of eco-app design.

Keywords: social media; information sources; eco-apps; pro-environmental behavior

\section{Introduction}

In the 21st century, information has become one of the most important goods and this is why the access and use of appropriate information sources, including the media, is so important. This applies to every area of socio-economic life; including shaping pro-environmental attitudes of students representing Generation Z. Pro-environmental behaviors of young people are a consequence and manifestation of various socio-consumer trends, mainly including conscious consumption, the ecologization of consumption and even deconsumption. They are also related to the climate change that an increasing part of humanity is experiencing, but are also correlated with changes in the media. The impact of consumption on the production of greenhouse gases and broadly understood climate change has been frequently discussed in the scientific literature. These analyzes concern activities undertaken at the international and national levels as well as in the context of individual households [1-7]. Researchers investigate relationships between the growing consumption involving increasing food and other commodities' wastage [8-10] and alternative forms of transport $[11,12]$ and climate change. These issues are also analyzed in the 
context of green economy or sustainable development $[13,14]$. The use of eco-applications is in line with the sustainable development goals announced by the United Nations in 2015 with a perspective until 2030, such as: Goal 4-Quality Education, Goal 9-Industry, Innovation and Infrastructure-focusing, inter alia, on supporting innovation, Goal 12Responsible Consumption and Production, and Goal 13-Climate Action-taking actions to combat climate change and its effects. Eco-applications are a tool that should be used in inclusive education (Goal 4) which can be provided to people of different age groups, places of residence and economic status [15].

The strategy to promote sustainable development in Poland is outlined in the strategic document adopted by the Ministry of Climate and Environment in 2019 entitled 2030 National Environmental Policy (PEP 2030) [16]. The sustainable development goals listed in PEP 2030 includes "Environmental education, including the shaping of sustainable development patterns" (point 7.12), which emphasizes that effective environmental protection requires the involvement of all citizens. This is why it is so important to build ecological awareness and shape pro-environmental attitudes by promoting the principles of sustainable development. Ideally, environmental education should involve the use of modern teaching methods and tools as well as reliable sources of information, e.g., eco-applications. This is why it appears valid to conduct research on eco-applications to make them a reliable, up-to-date and useful source of information and an educational instrument.

The medium that enables the acquisition, processing and generation of information is undoubtedly the internet, which has had the greatest impact on the style of media consumption and influencing the consumer. New media, including mobile applications, also foster the development of the sharing economy and facilitate conscious consumption. Already at the beginning of this century the literature identified basic regularity governing the internet, i.e., the new digital Darwinism, which predisposes only the loudest individuals, gaining as many positive opinions as possible, to survive, [17]. This is possible thanks to mobile applications that have become an integral part of the lives of internet users. The most popular apps in 2019 included: Facebook, Facebook Messenger, WhatsApp and Instagram (16 billion downloads). Such a great interest of users has not left entrepreneurs or scientists uninspired [18].

The media often creates attitudes and behaviors towards specific situations and objects. Therefore, various social and economic organizations use the media not only as a source of information, but also to influence the attitudes and behavior of consumers [19]. What is more, in the case of new media, the users are also active creators of information and opinions. Due to their easy access to the Internet, users become co-authors of the media content and increasingly often struggle not with access, but with selection of information. Digital technologies open up new, previously unknown opportunities for learning and satisfying information needs. The researchers exploring the media possibilities and potential include, inter alia: J. Sun [20], C. Thorun et al. [21] and M.S. Denner et al. [22]. World statistics clearly show a great interest in social media, especially of Generation Z [23]. The role of social media in searching for information by the group of young Internet users was studied by E. Roselina et al. [24], N. Guo, et al. [25], Gwijeong et al. [26] and I. Mir [27].

According to the report Digital 2020 [28], 3.80 billion users, i.e., 49\% of the world population, used social networking sites in 2020. The most popular platforms were Facebook ( 2.45 billion users), YouTube ( 2 billion users), WhatsApp (1.6 billion users) and Messenger (1.3 billion users). Notably, the time spent by users on social networking sites and applications was on average $2 \mathrm{~h}$ a day, which was $1 / 3$ of the time they used the internet $(6 \mathrm{~h}$ and $26 \mathrm{~min}$ ). For comparison, watching TV took on average $3 \mathrm{~h} 18 \mathrm{~min}$.

Social networking sites have become platforms for social interaction. Social media are interactive media using widely available, advanced and extensive communication techniques based on the internet and mobile technologies. Social media can be defined as a group of web-based applications that enable the creation and exchange of user-generated content [29]. J. Manning [30] sees social media as a term used to refer to new forms of media that include interactive participation. D. Miller et al. [31] define social media as "the 
colonization of the space between traditional broadcast and private dyadic communication, providing people with a scale of group size and degrees of privacy that we have termed scalable sociality".

M. Dorenda-Zaborowicz [32] points out that what all definitions of social media have in common is the connection of technology and interactivity, which results in the creation of new content. The common feature of modern and traditional media is the ability to attract a significant number of consumers. The features that distinguish social media from traditional ones include: range, access, use, immediacy and durability.

The interactive new media have become the main determinant of changes regarding the availability and reception of media content and its impact on the user attitudes. The main manifestations of these changes include [33]:

- continuous flow of users between different communication or media channels, i.e., the emergence of audience streams,

- fluid audience, changing in terms of size, intensity of contact and composition,

- increasing diversity and fragmentation of the audience,

- greater availability of content thanks to more networks,

- growing popularity of delayed viewing in relation initial airing-non-linear use of recorded content or services on demand,

- multiscreening, i.e., the phenomenon of using several devices at the same time to receive media content,

- binge-watching-compulsive watching of several episodes of a series at one go.

The growing importance of interactive media is a manifestation of socio-consumer trends. Referring to the research objectives addressed in this paper, the following trends should be mentioned: intelligent automation of society through 5G, virtual assistants (enabling the consumer to rely on information obtained from search engines and applications instead of their own knowledge) and the related "mental obesity" (automation of decisions through, for example, applications may result in minimizing mental effort and passing decision-making onto virtual assistants) and the Eco Me trend (using new technologies to make more environmentally conscious decisions). With regard to new technologies, these are, for example, smart watches that measure the daily carbon footprint of their owners, but in practice it is a series of activities that help reduce the negative impact of humans on the environment [34]. Ericsson ConsumerLab forecasts show that by 2030 the trends involving new media and communication technology will have intensified significantly [35].

Despite the many advantages of new media, there are also some disadvantages and some limitations. The most important is the lack of privacy and anonymity on the web, as well as the huge scale of communicated content, often leading to a low signal-to-noise ratio and the need to select information. Another disadvantage may be "smart quarrels", i.e., the incompatibility of information obtained from virtual assistants, which introduces noisy data and makes decisions difficult [35].

There is no doubt that media have changed the communication between a consumer and an entrepreneur, between entrepreneurs and between consumers themselves, i.e., between various stakeholders, both on the market and more broadly in the social space, but media impact is not the only determinant of pro-environmental behavior. Various other factors have impacts on pro-environmental behavior, including, in particular: demography, external factors (e.g., institutional, economic, social and cultural) and internal factors (e.g., motivation, knowledge about the environment, awareness, values, attitudes, emotions, location of control, responsibilities and priorities) [36]. Some researchers suggest that cosmopolitan individuals, being more open to the world's problems and sensitive to nature, tend to be more pro-environmentally committed [37]. It is precisely cosmopolitan attitudes that seem to prevail among students.

Pro-environmental behavior can be analyzed from the perspective of the rational choice theory. Its founders J.M. Buchanan and G. Tullock [38] assumed that the rationality of decision-making by an individual can also be understood as a willingness to act in order to maximize utility. Of course, also in the field of pro-environmental behavior, we will find 
behaviors motivated by impulses or inertia, but due to the complexity of such a resource as the natural environment and the inability to see the effects of human actions on this resource (as they are often delayed), decisions in this area most often fit the rational choice theory (maximize utility). However, F. Kaiser et al. [39] showed that the pro-environmental behavior of students can go beyond the rational choice theory. Their research shows that pro-environmental behavior is influenced by: environmental knowledge, environmental values and feelings of responsibility for the environment. These authors emphasized that rational choice theories do not sufficiently explain behavior that is at least partially moral, such as ecological behavior.

It might seem that in the era of universal access to the media and the high popularity of pro-environmental issues, due to Youth Climate Strike, the activity of Greta Thunberg, etc., there is an overabundance of information on the proper use of nature. However, various scientific studies emphasize that the demand for knowledge about human-nature interactions at the level of individuals and populations is still growing [40]. This may be the result of the fact that "objective knowledge is relatively low among the group of people who care about the environment" [41]. On the other hand, it is not possible to improve the quality of the environment without proper environmental education [42], which requires reliable sources of information $[43,44]$. Similar conclusions can be drawn from the research carried out among students which showed that the low level of environmental awareness results from a lack of knowledge [45] and lack of reliable sources of information. According to the report prepared by TNS Polska for the Ministry of the Environment [46], people aged 15-19 and 20-29 obtained information mainly from the internet (53\% and $62 \%$ respectively, while among people aged $60+$ this ratio was $17 \%$ ). The opinions of students from Olsztyn show that mass media (53.8\%) had the greatest impact on shaping their attitude to the natural environment, followed by school (41.3\%) and family (31.4\%) [47]. Similarly, young people from Bełchatów and its vicinity, one of the most polluted places in Poland, most often indicated the internet as a source of information (74\%) [48]. The research by M. Śmiechowska et al. shows that internet users approach information posted on the web with different confidence, and it depends on the age of the respondents. Younger people (aged 19-30) perceive the internet as more reliable than people over 30 [49]. In addition, the research of K. Kucinska [50] shows that the sources of environmental knowledge used by young people include both new and traditional media and, to a lesser extent, educational institutions.

The analysis of secondary data leads to the reflection that comparing the results of other authors' research should be approached with great caution. The studies are carried out at different times, in different countries and with the use of different research methods and techniques. There are also different ways of reaching the respondents. Therefore, we treat the research by other researchers as background for the analysis of the results of our own empirical research, indicating in the final part of the article the need for cooperation of scientists from various centers in order to carry out comparable scientific research.

The main objective of this study was to recognize the use of eco-applications as a new source of information in the field of pro-environmental behavior of young people studying in Poland and a factor shaping environmentally friendly attitudes.

The following specific objectives were addressed in this research:

1. Identifying the most often declared students' pro-environmental behaviors

2. Determining eco-apps recognition among students

3. Indicating the eco-app design features expected by students

This paper is organized as follows: The first section is a presentation of the approach to information and communication channels. The methodology section contains a detailed description of the methodology. The next part concerned the presentation of the research results and discussion. On the basis of the conducted analysis, conclusions were formulated and the limitations and implications for future research indicated. 


\section{Materials and Methods}

This study involved a desk research method, an in-depth interview and computerassisted web interviewing (CAWI). As part of the secondary data analysis, a review of scientific studies covering the issues of pro-environmental behavior of students and the role of new media in encouraging these behaviors was carried out. Using our own research experience, findings of other authors and information obtained during an in-depth interview with students of Warsaw University of Life Sciences, we created a questionnaire to conduct our own empirical research. The questionnaire was prepared on the Google platform. The link to the survey was sent through the Teams platform. The choice of such a method of carrying out empirical research resulted from both the nature of the studied area and the current epidemic situation that prevented direct contact with respondents. The questionnaire included filtering and multiple choice questions as well as rating questions with a five-point Likert scale. The questions covered: evaluation of respondents' own pro-environmental behavior, recognition and use of selected applications, assigning specific functions (roles) to eco-apps and indicating the features of the optimal pro-environmental application design.

The selection of the eco-apps for analysis was made in stages. First of all, from the database of available applications, those that met the pro-environmental criterion were selected (the apps aimed at reducing the negative impact on the environment). Then, an in-depth interview was conducted with a group of students (via the Teams platform), which allowed for the selection of applications that were identifiable by this group of consumers. The selected apps included: ZeroWasteApp, (an app which helps find favorite places for a zero-waste lifestyle such as bulk stores, zero-waste shops, vegan cafes and restaurants and waste-free activities); ZdroweZakupy (an app which analyzes the ingredients and nutritional values and shows their health impact after scanning the bar code on a food product; ToGoodToGo (an app which connects customers to restaurants and stores that have unsold food surplus), Ingred (an app which checks the product label for ingredients of cosmetics or food that can be harmful to health) GdzieWyrzucić (an app helping with waste sorting), Vinted (an online marketplace and community that allows its users to sell, buy, and swap new or secondhand items, mainly clothing and accessories), Veturilo (an app for users of city bike systems), BlaBlaCar (an app for car sharing) and HappyCow (an app which helps to find vegetarian and vegan restaurants). These applications were included in the survey. The logos of the analyzed applications were also placed in the questionnaire. After the survey was completed and the responses initially verified, the applications that had been the least often identified were rejected (the third stage of selecting applications for analysis). The rejected apps included ZeroWasteApp, Ingred and HappyCow. The remaining applications were statistically analyzed. The process of empirical research is presented in Table 1.

Table 1. Research stages.

\begin{tabular}{ccccc}
\hline I & II & III & V V & V \\
\hline $\begin{array}{c}\text { Development of a } \\
\text { survey questionnaire }\end{array}$ & $\begin{array}{c}\text { Testing of the } \\
\text { questionnaire among } \\
60 \text { respondents }\end{array}$ & $\begin{array}{c}\text { Checking the validity } \\
\text { of the questionnaire }\end{array}$ & $\begin{array}{c}\text { Conducting surveys } \\
\text { among } 829 \\
\text { respondents }\end{array}$ & $\begin{array}{c}\text { Selection and } \\
\text { rejection of } \\
\text { incomplete } \\
\text { questionnaires }\end{array}$ \\
\hline
\end{tabular}

Source: own study.

- The actual research was preceded by a pilot study that was carried out on a sample of 60 students on 15-16 March 2021 on the Teams platform. The pilot study made it possible to improve the questionnaire. The actual research was carried out in April 202. The study population included students of Warsaw universities representing Generation Z.

- Due to the diverse divisions of demographic cohorts in the literature, the study adopted the one proposed by Lyons, Schweitzer, and Eddy [34,51], in which Generation Z embraces people born after 1995, also known as C or "connect, communicate, change". 
A total of 829 questionnaires were returned, but after the initial selection and rejection of incomplete questionnaires, 772 questionnaires were qualified for analysis. The sample collection meets the conditions for the non-random sampling of typical units [52].

The following descriptive statistics measures were used in the analysis of the research material: mean, median and standard deviation. The differentiating variables were gender, place of residence and monthly household income per capita. The Mann-Whitney test and Kruskal-Wallis test were used to search for the relationship between gender, place of residence and income, and pro-environmental behavior, recognition and use of applications and the preferred features of eco-app design. The obtained results are presented in tabular and descriptive form.

The analysis of source materials made it possible to formulate the following research hypotheses:

Hypothesis 1 (H1). Students most often declare pro-environmental behavior in the household context.

Hypothesis 2 (H2). Young people studying in Poland most often recognize eco-applications promoted in traditional media.

Hypothesis 3 (H3). Polish language and the ease of use are the main features expected of ecoapp design.

\section{Results and Discussion}

The survey on mobile eco-applications in encouraging pro-environmental behavior in young people studying in Poland was conducted on a sample aged 17-25. The majority were women $(62.2 \%)$.

The respondents' place of residence varied. Most, $41.1 \%$, indicated cities with population over 500,000 residents. The rest declared: rural areas-25.4\%, towns under 50,000 residents$15.5 \%$ and cities with population of 50,000-500,000 residents-15\%. The differentiating variable adopted for this study was the household income per capita per month. The respondents declared the range over 3000 (664 Euro)-31.6\%; 2000-3000 (443-663 Euro)-33.7\%; 1000-2000 (222-442 Euro)-25.6\% and up to 1000 PLN (221 Euro)-9.1\%.

In order to verify the first hypothesis (H1), the respondents were asked to evaluate their own pro-environmental behaviors in and outside the household context on a fivepoint Likert scale (Table 2).

On the one hand, shared car transport (BlaBlaCar) was the least often used solution, which is justified by the fact that it is a relatively new idea, used for longer journeys and burdened with additional risk during the pandemic. On the other hand, the respondents indicated cycling or taking public transport rather than a car, for both environmental and health reasons. Similar results are reported by C. Hsu et al. [53], P. Cerutti et al. [54], although, with regard to the bike sharing system, they distinguish three main motivations for such attitudes, namely health and the environment, the impact on society and the cyclist's lifestyle.

The respondents also relatively rarely indicated buying food with the Fair Trade certification. This type of label is found on many products, including sweets, so this group of consumers should have come across such a certificate. However, for the respondents who took part in our survey this certificate was of marginal importance.

The respondents most often declared that they save water and sort waste i.e., proenvironmental behaviors in the household context, which positively verifies the first hypothesis (H1). According to C. Tapia-Fonllem et al. [55] this type of pro-environmental behavior of students shows significant interrelations with frugal, altruistic and equitable behaviors, which suggests the presence of a higher-order-factor which the authors identified as sustainable behavior 
The relationship between pro-environmental behaviors and differentiating variables such as gender, place of residence and income level was verified. For this purpose, the Mann-Whitney test (Table 3) and the Kruskal-Wallis test (Table 4) were used.

Table 2. Respondents' evaluation of their own pro-environmental behaviors on a five-point Likert scale.

\begin{tabular}{|c|c|c|c|c|}
\hline Symbol & Pro-Environmental Behaviors & $\mathbf{M}$ & ME & SD \\
\hline A & Sorting waste & 3.68 & 4 & 1.08 \\
\hline B & Taking public transport rather than a car & 2.99 & 3 & 1.45 \\
\hline $\mathrm{C}$ & Buying products in recycled packaging & 2.99 & 3 & 1.03 \\
\hline $\mathrm{D}$ & Buying organic food & 2.69 & 3 & 1.10 \\
\hline $\mathrm{E}$ & Buying "zero-waste" products & 2.42 & 2 & 1.13 \\
\hline $\mathrm{F}$ & $\begin{array}{l}\text { Packing fruit and vegetables in reusable } \\
\text { bags instead of single-use bags }\end{array}$ & 3.06 & 3 & 1.44 \\
\hline G & Saving water & 3.53 & 4 & 1.02 \\
\hline $\mathrm{H}$ & $\begin{array}{l}\text { Using eco-friendly laundry and cleaning } \\
\text { products }\end{array}$ & 2.24 & 2 & 1.11 \\
\hline I & $\begin{array}{l}\text { Walking instead of taking public transport } \\
\text { for short distance }\end{array}$ & 3.22 & 3 & 1.35 \\
\hline $\mathrm{J}$ & Buying second-hand clothes & 2.63 & 3 & 1.47 \\
\hline K & $\begin{array}{l}\text { Buying clothes with eco-labels } \\
\text { (environmental certification) }\end{array}$ & 2.21 & 2 & 1.14 \\
\hline $\mathrm{L}$ & Buying food with fair trade certification & 2.10 & 2 & 1.12 \\
\hline M & Getting around by bike & 3.00 & 3 & 1.40 \\
\hline $\mathrm{N}$ & Car sharing (e.g., Blablacar) & 2.07 & 1 & 1.32 \\
\hline
\end{tabular}

Source: own research. Note: M-mean, Me-median, SD-standard deviation.

Table 3. Differences in the respondents' evaluation of own pro-environmental behaviors by gender (Mann-Whitney test).

\begin{tabular}{|c|c|c|c|}
\hline Symbol & Pro-Environmental Behaviors & $\mathrm{Z}$ & $\mathbf{P}$ \\
\hline A & Sorting waste & 1.528 & 0.126 \\
\hline B & Taking public transport rather than a car & 2.109 & 0.035 \\
\hline $\mathrm{C}$ & Buying products in recycled packaging & 2.434 & 0.015 \\
\hline $\mathrm{D}$ & Buying organic food & 2.789 & 0.005 \\
\hline E & Buying food from "zero-waste" shelves & 3.948 & 0.000 \\
\hline F & Packing fruit and vegetables in reusable bags instead of single-use bags & 2.779 & 0.005 \\
\hline G & Saving water & -0.466 & 0.641 \\
\hline $\mathrm{H}$ & Using eco-friendly laundry and cleaning products & -0.752 & 0.452 \\
\hline I & Walking instead of taking public transport for short distance & 1.183 & 0.237 \\
\hline $\mathrm{J}$ & Buying second-hand clothes & 6.385 & 0.000 \\
\hline K & Buying clothes with eco-labels (environmental certification) & 2.332 & 0.020 \\
\hline $\mathrm{L}$ & Buying food with fair trade certification & 0.388 & 0.698 \\
\hline M & Getting around by bike & -1.724 & 0.085 \\
\hline $\mathrm{N}$ & Car sharing (e.g., BlaBlaCar) & 1.683 & 0.092 \\
\hline
\end{tabular}


There was a statistically significant difference in declarations of pro-environmental behavior between women and men. Women more often than men indicated pro-environmental behaviors related to shopping, i.e., the purchase of products in recycled packaging, organic food, zero-waste products and packing fruit and vegetables in reusable bags, not single-use, disposable bags. Women also significantly more often than men declared the purchase of second-hand clothes or new clothes with eco-labels and more often than men chose public transport rather than a car. The studies of R. Bach et al. show more frequent use of health-related applications by women [56]. Further, the studies by D. Brécard et al. [57], B. Saboya de Aragão et al. [58] found that in the selection of food products environmental aspects are more important for women than for men.

The conducted analysis of the data shows that residents of rural areas statistically significantly differed in their declarations from inhabitants of cities over 500,000 residents with regard to three forms of pro-environmental behavior. On the one hand, the residents of rural areas more often than residents of large cities indicated waste sorting, which may result from the fact that, unlike city residents, especially those living in multi-family housing, they have their waste collected individually and it is easy to identify people who sort waste incorrectly. On the other hand, residents of large cities, to a greater extent than residents of rural areas, indicated pro-environmental transportation solutions, which are available mainly in cities, i.e., taking public transport rather than a car or shared transport (e.g., BlaBlaCar). In the case of using public transport (parameter B), there was also a statistically significant difference between the other groups (Table 4).

The level of monthly household income per capita only in one case significantly differentiated the respondents' declarations regarding their pro-environmental behavior. People with the lowest income (up to PLN 1000/EUR 221) statistically more often than with the highest income (over PLN 3000/EUR 664) took public transport rather than a car $(p=0.021)$.

We also addressed the question about students' recognition and use of eco-applications (Table 5). In the second hypothesis (H2), it was assumed that the students will first of all recognize applications promoted in traditional media.

The most recognizable application and at the same time the most frequently used was Vinted, followed by Veturilo. Interestingly, four out of ten respondents indicated that they identified both applications even though they did not use them. The Vinted application is very intensively promoted in traditional media (television) and new media (internet), which allows for a positive verification of the second hypothesis.

The respondents who in the filtering questions indicated that they knew the given application (whether they used it or not) were asked to rate individual parameters describing the app on a five-point Likert scale. The obtained rating is presented in Table 6.

The application which, in the opinion of the respondents, provides knowledge and information facilitates purchasing decisions and confirms knowledge from other sources is ZdroweZakupy (analyzing food product labels). The respondents also appreciated GdzieWyrzucić (helping with waste sorting) as a source of knowledge (Table 6). These results correspond with the studies by K. Maichum et al. [59], which show that knowledge is more important for pro-environmental behavior than the influence of a family or peer group.

On the other hand, the ToGoodToGo (helping to save surplus food) and Vinted (online marketplace for second-hand clothes) applications make it easier for the respondents to make purchasing decisions. Knowledge from other sources is confirmed to the greatest extent by the following applications: ZdroweZakupy and GdzieWyrzucić. ToGoodToGo, Vinted and Veturilo (city bikes) are seen more as proof of being fashionable than other applications. All analyzed applications received relatively low scores in the following areas: prestige, standing out from the peer group and building credibility among friends. 
Table 4. Differences in the declaration of pro-environmental behaviors by the place of residence (Kruskal-Wallis test).

\begin{tabular}{|c|c|c|c|c|c|c|c|c|c|c|c|c|c|c|c|}
\hline \multirow[t]{2}{*}{ Symbol * } & \multicolumn{3}{|c|}{ Rural Areas (I) } & \multicolumn{3}{|c|}{ City Under 50,000 (II) } & \multicolumn{3}{|c|}{ City 50,000-500,000 (III) } & \multicolumn{3}{|c|}{ City Over 500,000 (IV) } & \multirow{2}{*}{$\mathbf{H}$} & \multirow{2}{*}{$\mathbf{P}$} & \multirow{2}{*}{ Differences between Groups } \\
\hline & $\mathbf{M}$ & $\mathrm{Me}$ & SD & $\mathbf{M}$ & $\mathrm{Me}$ & SD & $\mathbf{M}$ & Me & SD & $\mathbf{M}$ & Me & SD & & & \\
\hline $\mathrm{A}$ & 3.93 & 4 & 0.87 & 3.78 & 4 & 0.90 & 3.78 & 4 & 1.11 & 3.44 & 4 & 1.20 & 22.73 & 0.00 & I-IV \\
\hline $\mathrm{B}$ & 2.51 & 2 & 1.32 & 2.66 & 2 & 1.44 & 3.02 & 3 & 1.36 & 3.42 & 4 & 1.44 & 57.69 & 0.00 & I-III; I-IV;II-IV \\
\hline $\mathrm{C}$ & 2.92 & 3 & 1.04 & 2.87 & 3 & 0.96 & 3.16 & 3 & 0.92 & 3.03 & 3 & 1.09 & 6.43 & 0.09 & \\
\hline $\mathrm{D}$ & 2.56 & 2 & 1.01 & 2.66 & 3 & 1.08 & 2.84 & 3 & 1.10 & 2.74 & 3 & 1.16 & 5.95 & 0.11 & \\
\hline $\mathrm{E}$ & 2.30 & 2 & 1.17 & 2.36 & 2 & 1.00 & 2.42 & 2 & 1.16 & 2.52 & 3 & 1.15 & 4.53 & 0.21 & \\
\hline$F$ & 2.95 & 3 & 1.41 & 3.11 & 3 & 1.41 & 3.30 & 3 & 1.43 & 3.02 & 3 & 1.47 & 4.95 & 0.18 & \\
\hline G & 3.67 & 4 & 0.94 & 3.48 & 4 & 0.99 & 3.64 & 4 & 1.05 & 3.42 & 3 & 1.07 & 9.25 & 0.03 & \\
\hline $\mathrm{H}$ & 2.22 & 2 & 1.05 & 2.11 & 2 & 1.02 & 2.54 & 3 & 1.27 & 2.20 & 2 & 1.11 & 8.65 & 0.03 & \\
\hline I & 3.11 & 3 & 1.43 & 3.23 & 3 & 1.37 & 3.20 & 3 & 1.35 & 3.30 & 4 & 1.29 & 1.79 & 0.62 & \\
\hline $\mathrm{J}$ & 2.66 & 3 & 1.48 & 2.58 & 3 & 1.52 & 2.95 & 3 & 1.46 & 2.53 & 2 & 1.44 & 7.69 & 0.05 & \\
\hline $\mathrm{K}$ & 2.19 & 2 & 1.19 & 2.22 & 2 & 1.13 & 2.40 & 2 & 1.17 & 2.15 & 2 & 1.11 & 4.17 & 0.24 & \\
\hline $\mathrm{L}$ & 1.96 & 2 & 0.98 & 2.15 & 2 & 1.03 & 2.28 & 2 & 1.17 & 2.09 & 2 & 1.20 & 6.09 & 0.11 & \\
\hline $\mathrm{M}$ & 3.10 & 3 & 1.35 & 3.13 & 3 & 1.38 & 3.17 & 3 & 1.39 & 2.82 & 3 & 1.43 & 8.92 & 0.03 & \\
\hline
\end{tabular}

Source: own research. Note: H-value of the Kruskal-Wallis test, p-level of statistical significance. * Symbols correspond to pro-environmental behaviors from Tables 1 and 2.

Table 5. Recognition and use of eco-applications by respondents $(n=772, \%)$.

\begin{tabular}{|c|c|c|c|c|c|c|c|c|c|}
\hline \multirow{2}{*}{ Responses } & \multicolumn{9}{|c|}{ Applications } \\
\hline & Zdrowe Zakupy & To Good To Go & Gdzie Wyrzucić & Vinted & Veturilo & BlaBlaCar & Ingred * & ZeroWaste App * & Happy Cow * \\
\hline $\begin{array}{l}\text { I don't know } \\
\text { this app }\end{array}$ & 72.2 & 68.0 & 74.1 & 14.8 & 24.7 & 70.2 & 91.2 & 89.5 & 94.9 \\
\hline $\begin{array}{l}\text { I know this app } \\
\text { but I don't use it }\end{array}$ & 19.2 & 18.8 & 16.3 & 40.7 & 40.3 & 20.1 & 7.4 & 8.9 & 3.8 \\
\hline $\begin{array}{l}\text { I know this app } \\
\text { and I use it }\end{array}$ & 8.7 & 13.2 & 9.6 & 44.5 & 35.0 & 9.7 & 1.4 & 1.6 & 1.3 \\
\hline
\end{tabular}

Source: own research. Note: *Applications not included in further analysis. 
The Mann-Whitney test revealed the difference in the usefulness of individual applications between women and men. It was shown that statistically significantly more women than men indicated the usefulness of the following applications:

- ZdroweZakupy in confirmation of knowledge gained from other sources $(\mathrm{U}=204$, $p=0.0022)$

- $\quad$ GdzieWyrzucić in providing knowledge and information $(Z=2.157, p=0.031)$

- $\quad$ Vinted in providing knowledge and information $(Z=2.917, p=0.004)$

- Veturilo in providing knowledge and information $(Z=1.988, p=0.047)$, facilitating purchasing decisions $(Z=2.033, p=0.042)$, confirming knowledge from other sources $(Z=2.187, p=0.029)$, building prestige $(Z=2.381, p=0.017)$ and proof of being fashionable $(Z=2.463 ; p=0.014)$.

These findings are consistent with the results of the research by B. Saboy de Aragão et al. [58], which shows that women are more engaged in buying and consuming environmentally friendly products and their disposal and reuse.

In order to identify the difference in the usefulness of individual applications in the analyzed areas depending on the level of income, the Kruskal-Wallis test was used. It has been shown that people with declared monthly household income per capita not exceeding PLN 1000 (EUR 221) rated ToGoodToGo $(p=0.042)$ significantly higher than respondents with incomes of PLN 1000-2000 (EUR 222-442) and rated Vinted $(p=0.019)$ higher than respondents with an income of at least PLN 3000 (EUR 664), both in terms of prestige. On the other hand, respondents with incomes in the range of PLN 1000-2000 (EUR 222-442), to a greater extent than respondents with the highest income, appreciated the role of BlaBlaCar in facilitating decision-making $(p=0.041)$.

The place of residence also slightly differentiated the importance of individual functions of the analyzed applications. Using the Kruskal-Wallis test, it was shown that for rural residents it is significantly more important than for residents of cities under 50,000 to stand out from the peer group in relation to the ZdroweZakupy application $(p=0.048)$. Respondents from cities under 50,000 residents found facilitating making decisions $(p=0.008)$ in the case of GdzieWyrzucić significantly more important than residents of cities with population over 500,000 .

In order to verify the third hypothesis (H3) assuming that Polish language and the ease of use will be the most expected features of eco-app design, we asked the respondents to rate the app design features on a five-point Likert scale. The importance and parameters of optimal eco-apps design were discussed, among others, by E. Typhina [60], who pointed to the language and functions programmed in mobile social networking applications that influence user behavior. P. Grover et al. [61] wrote about the importance of functionality and self-management features of mobile applications for contemporary app users.

According to the respondents, the optimal application should primarily contain up-todate and reliable information, be easy to use and fast, use simple language and be available on various devices (Table 7). The requirement for the application to be in Polish was not the most important for the respondents, which means that the third hypothesis was only partially positively verified. 
Table 6. Assessment of the usefulness of individual eco-apps on a five-point Likert scale.

\begin{tabular}{|c|c|c|c|c|c|c|c|c|}
\hline Eco-Apps & & $\begin{array}{c}\text { Provides } \\
\text { Knowledge and } \\
\text { Information }\end{array}$ & $\begin{array}{c}\text { Facilitates } \\
\text { Purchasing } \\
\text { Decisions }\end{array}$ & $\begin{array}{c}\text { Confirms } \\
\text { Knowledge from } \\
\text { Other Sources }\end{array}$ & $\begin{array}{c}\text { It Is a Symbol of } \\
\text { Prestige }\end{array}$ & $\begin{array}{c}\text { Builds } \\
\text { Credibility in a } \\
\text { Group of Friends }\end{array}$ & $\begin{array}{c}\text { Makes You Stand } \\
\text { Out from the Peer } \\
\text { Group }\end{array}$ & $\begin{array}{c}\text { Confirms You Follow } \\
\text { Trends/Are } \\
\text { Fashionable }\end{array}$ \\
\hline \multirow{3}{*}{$\begin{array}{c}\text { Zdrowe } \\
\text { Zakupy }(n=67)\end{array}$} & M & 3.99 & 3.96 & 3.58 & 2.07 & 2.10 & 2.15 & 2.25 \\
\hline & $\mathrm{Me}$ & 4 & 4 & 4 & 2 & 2 & 2 & 2 \\
\hline & $\mathrm{SD}$ & 1.04 & 1.17 & 1.08 & 1.16 & 1.17 & 1.21 & 1.19 \\
\hline \multirow{3}{*}{$\begin{array}{c}\text { ToGood } \\
\text { ToGo }(n=102)\end{array}$} & M & 3.17 & 3.65 & 3.09 & 2.41 & 2.78 & 2.89 & 3.15 \\
\hline & $\mathrm{Me}$ & 3 & 4 & 3 & 2 & 3 & 3 & 3 \\
\hline & $\mathrm{SD}$ & 1,24 & 1,05 & 1,24 & 1,19 & 1,27 & 1,36 & 1,41 \\
\hline \multirow{3}{*}{$\begin{array}{c}\text { Gdzie } \\
\text { Wyrzucić }(n=74)\end{array}$} & M & 3.81 & 3.42 & 3.47 & 2.73 & 2.66 & 2.81 & 2.93 \\
\hline & $\mathrm{Me}$ & 4 & 3 & 3 & 3 & 3 & 3 & 3 \\
\hline & SD & 1.15 & 1.10 & 0.95 & 1.16 & 1.14 & 1.13 & 1.21 \\
\hline \multirow[b]{2}{*}{ Vinted $(n=342)$} & M & 2.77 & 3.61 & 2.67 & 2.24 & 2.50 & 2.56 & 3.05 \\
\hline & $\mathrm{Me}$ & 3 & 4 & 3 & 2 & 3 & 3 & 3 \\
\hline \multirow{3}{*}{ Veturilo $(n=268)$} & M & 2.76 & 2.76 & 2.60 & 2.35 & 2.53 & 2.59 & 3.06 \\
\hline & $\mathrm{Me}$ & 3 & 3 & 3 & 2 & 2.5 & 3 & 3 \\
\hline & SD & 1.34 & 1.37 & 1.27 & 1.24 & 1.26 & 1.31 & 1.31 \\
\hline \multirow{3}{*}{ BlaBlaCar $(n=75)$} & M & 2.75 & 2.73 & 2.59 & 2.21 & 2.47 & 2.47 & 2.72 \\
\hline & $\mathrm{Me}$ & 3 & 3 & 3 & 2 & 3 & 2 & 3 \\
\hline & SD & 1.39 & 1.35 & 1.37 & 1.24 & 1.27 & 1.24 & 1.36 \\
\hline
\end{tabular}


Table 7. Expected features of an optimal eco-app design rated on a five-point Likert scale $(n=772)$.

\begin{tabular}{|c|c|c|c|}
\hline Eco-App Should: & $\mathbf{M}$ & Me & SD \\
\hline Include all pro-environmental elements/multi-sector information & 3.7 & 4 & 1.160 \\
\hline Include only one sector of environmental activities, e.g., food & 3.2 & 3 & 1.236 \\
\hline Include up-to-date and reliable information & 4.6 & 5 & 0.933 \\
\hline Be available on a variety of devices & 4.5 & 5 & 0.982 \\
\hline Be easy to use & 4.6 & 5 & 0.906 \\
\hline Be Fast & 4.5 & 5 & 0.923 \\
\hline Use simple language & 4.5 & 5 & 0.924 \\
\hline Fail-safe & 4.3 & 5 & 0.967 \\
\hline Be in Polish & 3.9 & 4 & 1.153 \\
\hline Stimulate user engagement & 3.2 & 3 & 1.080 \\
\hline Be visually attractive (pleasing to the eye) & 4.2 & 4 & 0.965 \\
\hline
\end{tabular}

Source: own research.

The dependence of the expected app design features on gender, place of residence and income level of the respondents was verified. The Mann-Whitney $\mathrm{Z}$ test revealed that apart from the expectation that the application would cover only one sector of pro-environmental activities, e.g., food, all the others were significantly more expected by women than men.

The place of residence only slightly differentiated the choice of the features of the optimal eco-app design (in this case the Kruskal-Wallis test was used). Respondents living in rural areas were more likely to expect the app to be in Polish than respondents living in cities with populations over 500,000 $(p=0.048)$ and to a greater extent than residents of cities with populations of 50,000 to 500,000 expected the app to be fail-safe $(p=0.034)$. Using the Kruskal-Wallis test, it was also verified whether the level of income is a variable differentiating the perception of the features of an optimal pro-environmental app design. It has been shown that for people with incomes ranging from PLN 2000 to PLN 3000 (EUR 443-663) and over PLN 3000 (EUR 664), the timeliness and credibility of information is significantly more important than for people with incomes of up to PLN 1000 (EUR 221) ( $p$ value: 0.021 and 0.041 respectively). On the other hand, for the lowestincome respondents, the feature defined as "stimulating user engagement" $(p=0.015)$ was significantly more important than for the respondents with the highest-income.

\section{Implications}

The analysis of secondary data and the results of our empirical research support the following implications:

A. Policy:

1. Our research results contribute to the activities undertaken in the field of environmental education as part of 2030 National Environmental Policy (PEP 2030), as well as Goal 4-Education Quality and Goal 9 concerning the promotion of innovation contained in Sustainable Development Goals announced by the United Nations.

2. Knowledge about environmental protection should be taken into account to a greater extent in developing educational policy at all levels (from primary schools to universities) in order to effectively encourage the pro-environmental behavior of subsequent generations of consumers. 
3. The economic factor is a significant stimulus for pro-ecological behavior. Responding to the rational behavior of consumers, it is worth considering this aspect in the design of eco-apps and their correlation with the environmental policy implemented at the local, regional and even global level.

4. Due to the role of traditional media in supporting environmental education, national media policy should include mechanisms favoring the processes of convergence and pluralism.

B. Practice:

1. The research results have practical implications for companies dealing with the development of eco-applications. Adapting to user expectations is always preceded by a thorough needs analysis.

2. Green applications should be included in standard software packages for smartphones and should be correlated with various platforms, such as e-mail, ebanking or a communication platform. This procedure, (called an "enforced agreement" in the Ericsson ConsumerLab report [34]), may raise doubts, but it should influence appropriate consumer behavior.

C. Science:

1. It would be advisable to diagnose the reasons why traditional media are an effective tool for promoting eco-applications.

2. We believe that our research may inspire further research in this field at both the national and international levels

\section{Conclusions}

Mobile applications and their importance for the contemporary user have been discussed in many research studies covering almost every aspect of life. In the area of health, the topic was discussed, among others, by: S. Surendran et al. [62], J. Li et al. [63] and H. Zhang et al. [64]. In the field of economics, the importance and possibilities of using mobile applications were examined by H. Ouyang et al. [65], A. Ngubelanga [66], H. Karjaluoto [67] and many others. Mobile applications are also used in the area of environmental protection, as mentioned in the studies by A. Quandt et al. [68] and Y. Zhang et al. [69]. There are also many publications dealing with the issue of using applications in the aspect of managing a small and medium-sized enterprise e.g., N. Islami et al. [70] and R. Taher et al. [71]. All authors emphasize the importance of mobile applications in the broadly understood aspect of human life and activity. The use of mobile apps to promote pro-environmental behavior is currently one of the most important applications of this technology, able to effectively contribute to the protection of the natural environment. This aspect was broadly discussed in the article by M. Tosi et al. [72].

We believe that the conducted research further broadens the knowledge in the field of mobile applications in the narrow scope concerning the encouragement of pro-environmental behaviors, which has not been analyzed extensively in the literature. The presented research findings provide guidelines for designing useful mobile applications in the field of broadly understood pro-environmental-behavior. The analysis of the collected dataset fully confirmed two and partly one of the hypotheses put forward in the Methodology section this paper. The respondents mainly declared pro-environmental behavior in the household context. Interestingly, the eco-app promoted in traditional media was the most recognizable one, which suggests that this channel is effective for disseminating knowledge about ecoapplications. The analysis showed that the features young users look for in eco-apps include reliable information, regular content updates and ease of use. An important implication is the need to customize the content of the application taking into account the gender of the user. The requirement for the app to be in Polish language, assumed in the third hypothesis, was not seen as very important, which justifies the conclusion that the third hypothesis was only partially positively verified. 
To sum up, the results of the conducted research constitute a valuable source of information for entrepreneurs/developers dealing with the creation of eco-applications, whose target group are young people. Satisfying user expectations is possible only when the design process is preceded by a thorough analysis of user needs.

Each study has limitations resulting from the way it has been conducted, the scope or the sample. Clearly, our study has some limitations, too. First, the mere conducting of an online survey excludes the observation technique. Second, the study focused only on a few selected eco-applications. Third, only students of social sciences took part in this research and the sample included a relatively small group of respondents living in rural areas.

The obtained results are related to the empirical context of the research. There is a need to broaden the research area to include the eco-apps users' behavior. Creating environmentally friendly behavior is possible through a communication system that meets the expectations of various socio-demographic groups.

In addition, the study needs to be expanded in terms of quantity and an international approach. Certainly including other age groups would give a broader picture of attitudes towards the natural environment. As most of the respondents recognized the applications promoted in traditional media, it would be necessary to diagnose the reasons why traditional media is an effective channel for promoting eco-applications.

Author Contributions: The paper is the joint efforts of the authors, their contributions are equal on conceptualisation, methodology, analysis, investigation, resources, and writing-review and editing. All authors have read and agreed to the published version of the manuscript.

Funding: This research received no external funding.

Informed Consent Statement: Informed consent was obtained from all subjects involved in the study.

Conflicts of Interest: The autohrs declare no conflict of interest.

\section{References}

1. Knight, K.W.; Schor, J.B. Economic growth and climate change: A cross-national analysis of territorial and consumption-based carbon emissions in high-income countries. Sustainability 2014, 6, 3722-3731. [CrossRef]

2. Grigoryev, L.; Makarov, I.; Sokolova, A.; Pavlyushina, V.; Stepanov, I. Climate change and inequality: How to solve these problems jointly? Int. Organ. Res. J. 2020, 15, 1-31. Available online: https://mpra.ub.uni-muenchen.de/102346/1/MPRA_paper_102346 .pdf (accessed on 1 August 2021).

3. Sarkodie, S.A.; Adams, S.; Leirvik, T. Foreign direct investment and renewable energy in climate change mitigation: Does governance matter? J. Clean. Prod. 2020, 263, 121262. [CrossRef]

4. Zheng, S.; Huang, G.; Zhou, X.; Zhu, X. Climate-change impacts on electricity demands at a metropolitan scale: A case study of Guangzhou, China. Appl. Energy 2020, 261, 114295. [CrossRef]

5. Jakučionytė-Skodienè, M.; Dagiliūtè, R.; Liobikienė, G. Do general pro-environmental behavior, attitude, and knowledge contribute to energy savings and climate change mitigation in the residential sector? Energy 2020, 193, 116784. [CrossRef]

6. UNWTO. Transport-related CO2 Emissions of the Tourism Sector Modelling Results. Available online: https: / / www.e-unwto. org/doi/pdf/10.18111/9789284416660 (accessed on 2 August 2021).

7. Kurniawan, T.A.; Avtar, R.; Singh, D.; Xue, W.; Othman, M.H.D.; Hwang, G.H.; Iswanto, I.; Albadarin, A.B.; Kern, A.O. Reforming MSWM in Sukunan (Yogjakarta, Indonesia): A case-study of applying a zero-waste approach based on circular economy paradigm. J. Clean. Prod. 2021, 284, 124775. [CrossRef] [PubMed]

8. Pong, V. Global versus local framing of the issue of food waste: The role of identification with all humanity and the impli-cations for climate change communication. Soc. Psychol. Clim. Chang. 2021, 24, 221-231. [CrossRef]

9. Reynolds, C. Food waste, sustainable diets and climate change Coherent solutions in the long view. Paper presented at the Food Values Research Group Seminar. Available online: https:/ / arts.adelaide.edu.au/humanities/food-values/news/list/2021/07/ 04/food-waste-sustainable-diets-and-climate-change-coherent-solutions-in-the-long (accessed on 1 August 2021).

10. Reisch, L.A.; Sunstein, C.R.; Andor, M.A.; Doebbe, F.C.; Meier, J.; Haddaway, N.R. Mitigating climate change via food consumption and food waste: A systematic map of behavioral interventions. J. Clean. Prod. 2021, 279, 123717. [CrossRef]

11. Heaney, A.K.; Carrión, D.; Burkart, K.; Lesk, C.; Jack, D. Climate change and physical activity: Estimated impacts of ambient temperatures on bikeshare usage in New York city. Environ. Health Perspect. 2019, 127, 037002. [CrossRef]

12. Singh, Y.J. Is smart mobility also gender-smart? J. Gender Stud. 2019, 29, 832-846. [CrossRef]

13. Cebrián, G.; Junyent, M.; Mulà, I. Competencies in education for sustainable development: Emerging teaching and research developments. Sustainability 2020, 12, 579. [CrossRef] 
14. Rashed, A.H.; Shah, A. The role of private sector in the implementation of sustainable development goals. Environ. Dev. Sustain. 2021, 23, 2931-2948. [CrossRef]

15. Agenda 2030 na Rzecz Zrównoważonego Rozwoju—Implementacja w Polsce. Available online: http://www.un.org.pl/files/17 0/Agenda2030PL_pl-5.pdf (accessed on 1 August 2021).

16. Polityka Ekologiczna Państwa 2030-Strategia Rozwoju w Obszarze Środowiska i Gospodarki Wodnej. Available online: https:/ / www.gov.pl/web/srodowisko/polityka-ekologiczna-panstwa-2030--strategia-rozwoju-w-obszarze-srodowiska-igospodarki-wodnej?fbclid=IwAR0j6u3nGSIVYwlRhbgCdelXIVqyKCHp76yQnEwWvjnPohjEIlDJ9j7v5ps (accessed on 1 August 2021).

17. Kotler, P.G.; Armstrong, G. Marketing Podręcznik Europejski; Polskie Wydawnictwo Ekonomiczne: Warszawa, Poland, $2002 ;$ p. 57.

18. Ranking: Najcześciej Pobierane Aplikacje na Świecie w 2019 Roku. Available online: https://www.visualcapitalist.com/ (accessed on 5 June 2021).

19. Mrozowski, M. Przenikanie Mediów. Ewolucja Mediów a Przemiany Ładu Społecznego; Wydawnictwo PWN: Warszawa, Poland, 2020.

20. Sun, J. Research on the credibility of social media information based on user perception. Sec. Commun. Netw. 2021, 2021, 5567610. [CrossRef]

21. Thorun, C.; Diels, J. Consumer protection technologies: An investigation into the potentials of new digital technologies for consumer policy. J. Consum. Policy 2020, 43, 177-191. [CrossRef]

22. Denner, M.S.; Püschel, L.C.; Röglinger, M. How to exploit the digitalization potential of business processes. Bus. Inform. Syst. Eng. 2018, 60, 331-349. [CrossRef]

23. Reinikainen, H.; Kari, J.T.; Luoma-aho, V. Generation Z and organizational listening on social media. Media Commun. 2020, 8, 185-196. [CrossRef]

24. Roselina, E.; Asmiyanto, T.; Andriany, M. Health information-seeking behavior on the COVID-19 pandemic: Social media usage by gen Z in Jakarta, Indonesia. Libr. Philos. Pract. 2021, 1-7. Available online: https://digitalcommons.unl.edu/libphilprac/4920/ (accessed on 15 May 2021).

25. Guo, N.; Guo, Z.; Zhao, S.; Sai, Y.H.; Fong, D.Y.T.; Lai, A.Y.K.; Chan, S.S.; Wang, M.P.; Lam, T.H. Digital inequalities in health information seeking behaviors and experiences in the age of web 2.0: A population-based study in Hong Kong. PLoS ONE 2021, 16, e0249400. [CrossRef] [PubMed]

26. Park, G.; Chen, F.; Cheng, L. A study on the millennials usage behavior of social network services: Effects of motivation, density, and centrality on continuous intention to use. Sustainability 2021, 13, 2680. [CrossRef]

27. Mir, I.A. Dimensionality and effects of information motivation on users' online social network advertising acceptance. Rev. Adm. Empresas 2018, 58, 174-187. [CrossRef]

28. Digital 2020. Available online: www.hootsuite.com/resources/digital-2020 (accessed on 5 June 2021).

29. Baumöl, U.; Hollebeek, L.; Jung, R. Dynamics of customer interaction on social media platforms. Electron. Mark. 2016, 26, 199-202. [CrossRef]

30. Manning, J. Social media, definition and classes of. In Encyclopedia of Social Media and Politics; Harvey, K., Ed.; SAGE Publications: Thousand Oaks, CA, USA, 2014; pp. 1158-1162.

31. Miller, D.; Costa, E.; Haynes, N.; McDonald, T.; Nicolescu, R.; Sinanan, J.; Wang, X. How the World Changed Social Media; UCL Press: London, UK, 2016; p. 9.

32. Dorenda-Zaborowicz, M. Marketing w social media. In Nowe Media; Uniwerystet Mikołaja Kopernika w Toruniu (Nicolaus Copernicus University in Toruń) Springer: Cham, Switzerland, 2012; p. 60.

33. Jaska, E.; Werenowska, A. Komunikacja Przedsiębiorstwa z Otoczeniem w Gospodarce Opartej na Wiedzy; Wydawnictwo SGGW: Warszawa, Poland, 2017.

34. Available online: www.ericsson.com/en/reports-and-papers/consumerlab/reports/10-hot-consumer-trends-2019 (accessed on 4 August 2021).

35. Available online: www.ericsson.com/en/reports-and-papers/consumerlab/reports/10-hot-consumer-trends-2030-connectedintelligent-machines (accessed on 4 August 2021).

36. Kollmuss, A.; Agyeman, J. Mind the gap: Why do people act environmentally and what are the barriers to pro-environmental behaviour? Environ. Educ. Res. 2002, 8, 239-260. [CrossRef]

37. Ito, K.; Leungb, A.K.-Y.; Huangb, T. Why do cosmopolitan individuals tend to be more pro-environmentally committed? The mediating pathways via knowledge acquisition and emotional affinity toward nature. J. Environ. Psychol. 2020, 68. [CrossRef]

38. Ptak, P. Idywidualizm metodologiczny Jamesa Buchanana i jego implikacje praktyczne. Stud. Ekon. Zesz. Nauk. Uniw. Ekon. Katow. 2018, 349, 192-200.

39. Kaiser, F.G.; Ranney, M.; Hartig, T.; Bowler, P.A. Ecological behavior, environmental attitude, and feelings of responsibility for the environment. Eur. Psychol. 1999, 4, 59-74. [CrossRef]

40. Gaston, K.J.; Soga, M.; Duffy, J.P.; Garrett, J.K.; Gaston, S.; Cox, D.T.C. Personalised ecology. Trends Ecol. Evol. 2018, 33, 916-925. [CrossRef]

41. Ellen, P.S. Do we know what we need to know? Objective and subjective knowledge effects on pro-environmental behaviors. J. Bus. Res. 1994, 30, 43-52. [CrossRef]

42. Escher, I.; Petrykowska, J. Pro-environmental behaviours of young polish consumers. Handel Wewn. 2015, 2, 128-141. 
43. Patrzałek, W. The importance of ecological awareness in consumer behavior. Res. Pap. Wroc. Univ. Econ. 2017, 501, 11-23. [CrossRef]

44. Kwiatek, A.; Skiba, M. Ecological awareness of young people. Zesz. Nauk. Politech. Częst. Zarz. 2017, 28, 127-136. [CrossRef]

45. Bednarek-Gejo, A.; Mianowany, M.; Skoczylas, P.; Głowacka, A. Environmental awareness of students. Hygeia Public Health 2012, 47, 201-206.

46. Trackingowe Badanie Świadomości i Zachowań Ekologicznych Mieszkańców Polski; Raport z badania wrzesień 2018 Opracowane dla Ministerstwa Środowiska przez konsorcjum firm DANAE sp. z o.o. (Lider Konsorcjum) oraz Realizacja sp. z o.o. Available online: www.gov.pl/web/srodowisko (accessed on 1 September 2020).

47. Szulborski, K.D. Ecological consciousness of teenagers in postmodernism's society. Hum. Przyr. 2001, 48, 137-148.

48. Results of the Environmental Awareness Survey among Young People Living in and near Bełchatów. October 2019. [Prepared by: Ośrodek Działań Ekologicznych „Źródła” from Łódź as part of the project “Just Transition. Bełchatów], 2050; p. 7. Available online: https:/ / belchatow2050.pl/wp-content/uploads/2020/08/raport_belchatow-2050.pdf (accessed on 25 June 2021).

49. Śmiechowska, M.; Newerli-Guz, J.; Kakol, J. The role of electronic media in shaping the ecological awareness of the society. J. Res. Appl. Agric. Eng. 2009, 54, 140-147.

50. Kucińska, K. Knowledge about organic food among citizens of Warsaw. J. Res. Appl. Agric. Eng. 2009, 54, $164-172$.

51. Lyons, S.T.; Schweitzer, L.; Eddy, S.W. How have careers changed? An investigation of changing career patterns across four generations. J. Manag. Psychol. 2015, 30, 8-21. [CrossRef]

52. Frankfort-Nachmias, C.; Nachmias, D. Metody Badawcze w Naukach Społecznych; Wydawnictwo Zyska i S-ka: Poznań, Poland, 2001.

53. Hsu, C.C.; Liou, J.J.H.; Lo, H.W.; Wang, Y.C. Using a hybrid method for evaluating and improving the service quality of public bike-sharing systems. J. Clean. Prod. 2018, 202, 1131-1144. [CrossRef]

54. Cerutti, P.S.; Martins, R.D.; Macke, J.; Sarate, J.A.R. Green, but not as green as that: An analysis of a Brazilian bike-sharing system. J. Clean. Prod. 2019, 217, 185-193. [CrossRef]

55. Tapia-Fonllem, C.; Corral-Verdugo, V.; Fraijo-Sing, B.; Durón-Ramos, M.F. Assessing sustainable behavior and its correlates: A measure of pro-environmental, frugal, altruistic and equitable actions. Sustainability 2013, 5, 711-723. [CrossRef]

56. Bach, R.L.; Wenz, A. Studying health-related internet and mobile device use using web logs and smartphone records. PLoS ONE 2020, 15. [CrossRef]

57. Brécarda, D.; Hlaimib, B.; Lucasa, S.; Perraudeaua, Y.; Salladarréa, F. Determinants of demand for green products: An application to eco-label demand for fish in Europe. Ecol. Econ. 2009, 69, 115-125. [CrossRef]

58. Saboya de Aragão, B.; Alfinito, S. The relationship between human values and conscious ecological behavior among consumers: Evidence from Brazil. Clean. Responsib. Consum. 2021, 3, 100024. [CrossRef]

59. Maichum, K.; Parichatnon, S.; Peng, K.-C. Application of the extended theory of planned behavior model to investigate purchase intention of green products among thai consumers. Sustainability 2016, 8, 77. [CrossRef]

60. Typhina, E. Eco-apps: Design to influence environmentally friendly behavior. Int. J. E-Serv. Mob. Appl. 2015, 7, 1-21. [CrossRef]

61. Grover, P.S.; Aggarwal, P.K.; Ahuja, L. Evaluating self-management features for mobile applications. Int. J. E-Serv. Mob. Appl. 2019, 11, 43-55. [CrossRef]

62. Surendran, S.; Lim, C.S.; Gerald Choon, H.K.; Tong, W.Y.; Tai, E.S.; Foong, P.S. Women's usage behavior and perceived usefulness with using a mobile health application for gestational diabetes mellitus: Mixed-methods study. Int. J. Environ. Res. Public Health 2021, 18, 6670. [CrossRef] [PubMed]

63. Li, J.; Chang, X. Improving mobile health apps usage: A quantitative study on mPower data of Parkinson's disease. Inform. Technol. People 2021, 34, 399-420. [CrossRef]

64. Zhang, H.; Dimitrov, D.; Simpson, L.; Plaks, N.; Singh, B.; Penney, S.; Landman, A. A web-based, mobile-responsive application to screen health care workers for COVID-19 symptoms: Rapid design, deployment, and usage. JMIR Form. Res. 2020, 4. [CrossRef]

65. Ouyang, H.; Zhi, Y.; Wu, B. A study on default prediction of Chinese online lending: Based on the analysis of mobile phone usage data. Appl. Econ. Lett. 2021, 28, 686-690. [CrossRef]

66. Ngubelanga, A. Modeling mobile commerce applications' antecedents of customer satisfaction among millennials: An extended TAM perspective. Sustainability 2021, 13, 5973. [CrossRef]

67. Karjaluoto, H.; Glavee-Geo, R.; Ramdhony, D.; Shaikh, A.A.; Hurpaul, A. Consumption values and mobile banking services: Understanding the urban-rural dichotomy in a developing economy. Int. J. Bank Mark. 2021, 39, 272-293. [CrossRef]

68. Quandt, A.; Herrick, J.; Peacock, G.; Salley, S.; Buni, A.; Mkalawa, C.C.; Neff, J. A standardized land capability classification system for land evaluation using mobile phone technology. J. Soil Water Conserv. 2020, 75. [CrossRef]

69. Zhang, Y.; Shaoqiang, G.; Kekuo, Y.; Shunli, H.; Zaiqiang, H. Application of remote sensing technology in land use survey of mining area. IOP Conf. Ser. Earth Environ. Sci. 2021, 643. [CrossRef]

70. Islami, N.N.; Wahyuni, S.; Puji, R.P.N. Digital literation of micro, small and medium enterprises (MSMEs) in Jember district. IOP Conf. Ser. Earth Environ. Sci. 2021, 747, 012097. [CrossRef]

71. Taher, R.A.; Norouzi, E.; Omidi, A.; Valero-Pastor, J. Competitive strategies of mobile applications in online taxi services: The cases of snapp and Tap30 in Iran. Int. J. Emerg. Mark. 2021, 16, 113-130. [CrossRef]

72. Tosi, M.; Radice, D.; Carioni, G.; Vecchiati, T.; Fiori, F.; Parpinel, M.; Gnagnarella, P. Accuracy of applications to monitor food intake: Evaluation by comparison with 3-d food diary. Nutrition 2021, 84, 111018. [CrossRef] 